\title{
Novel tetranucleotide microsatellite markers for Chinese beard eel (Cirrhimuraena chinensis Kaup)
}

\author{
H. Li ${ }^{1}$, T.M. Ge ${ }^{2}$, S.X. Ding ${ }^{1}$ and H.J. Wang ${ }^{1}$ \\ ${ }^{1}$ State Key Laboratory of Marine Environmental Science, Xiamen University, \\ Xiamen, Fujian, China \\ ${ }^{2}$ Hubei Key Laboratory of Wetland Evolution and Ecological Restoration, \\ China University of Geosciences, Wuhan, Hubei, China \\ Corresponding author: S.X. Ding \\ E-mail: sxding@xmu.edu.cn
}

Genet. Mol. Res. 12 (3): 2779-2782 (2013)

Received January 15, 2012

Accepted June 5, 2013

Published August 2, 2013

DOI http://dx.doi.org/10.4238/2013.August.2.3

\begin{abstract}
In this study, we characterized 12 novel polymorphic microsatellite loci for Chinese beard eel (Cirrhimuraena chinensis Kaup) from a tetranucleotide microsatellite-enriched library. Loci screened on a sample of 37 individuals from Xiamen wild stocks revealed 8 to 24 alleles per locus, with a mean of 13.83 over all loci. Observed and expected heterozygosities ranged from 0.270 to 0.944 and 0.439 to 0.942 , respectively. These efficient genetic markers thus provide useful tools in the study of the population genetics and phylogeography of Chinese beard eel.
\end{abstract}

Key words: Chinese beard eel; Cirrhimuraena chinensis Kaup; Microsatellite 


\section{INTRODUCTION}

The Chinese beard eel (Cirrhimuraena chinensis Kaup) is one of the nearshore warm-water demersal fishes, which spreads widely from the eastern coast of Indo-Africa to Indonesia, China, and the Philippines. In China, it occurs along the coastal areas of the East China Sea, Taiwan Strait, and South China Sea (Zhu, 1984). It inhabits the sandy shallows of estuaries and burrows of low intertidal zones, and is generally considered to be a resident fish without long-distance swimming ability (Liu et al., 2005). In addition, it experiences a metamorphosis stage of leptocephalus in its life cycle (Zhang et al., 1982), as do most Anguilliformes fishes. These factors suggest that the population of $C$. chinensis may be sensitive to local environmental conditions and have different dispersal rates in the larval and adult stages. Thus, Chinese beard eel could be regarded as a favorable environmental monitoring candidate of local habitats. However, little genetic information is currently available and no studies on its population structure have been reported yet.

Microsatellite markers are extensively applied in genetic studies for their superiority of abundance, co-dominance, easy detection, and high polymorphism (Aggarwal et al., 2004). In order to avoid mistyping the real alleles, a tetranucleotide repeat motif strategy was used to make the stutter bands less common (Hoffman and Amos, 2005). Here, we describe the isolation and characterization of 12 polymorphic microsatellite markers for Chinese beard eel.

\section{MATERIAL AND METHODS}

Samples of Chinese beard eel were captured from Xiamen wild stocks. To construct a microsatellite-enriched library, genomic DNA was isolated from muscle tissue originally collected and stored in ethanol absolute, using a standard traditional phenol-chloroform procedure (Sambrook et al., 1989). The microsatellites were enriched according to the FIASCO protocol (Zane et al., 2002), with little modifications: approximately 250 ng genomic DNA was simultaneously digested with $C v i \mathrm{QI}$ and ligated to a $C v i \mathrm{QI}$ adaptor (5'-TAGTCAGGACTCAT$3^{\prime} / 5^{\prime}-$ GACGATGAGTCCTGAC-3') overnight at $25^{\circ} \mathrm{C}$. The digestion-ligation mixture was diluted (1:10), and directly amplified in a total volume of $20 \mu \mathrm{L}$ with a pig-tailed $C v i \mathrm{QI}-\mathrm{N}$ primer (5'-GTTTGACGATGAGTCCTGACTACN-3'). Biotinylated (GATA) ${ }_{6}$ and (AAAT) 6 were used as probes. The probe hybridization and capture of the probe-hybridized DNA by Streptavidin MagneSphere ${ }^{\circledR}$ paramagnetic particle (Promega) methods followed the protocol of Zane et al. (2002). After 3 nonstringency washes and 3 stringency washes, the recovered DNAs were amplified by 24 cycles of PCR using the above-mentioned primer. The PCR products were then purified and ligated into the PMD18-T vector (TaKaRa) and transformed into DH5 $\alpha$ competent cells. A total of 214 positive clones selected randomly from the enriched library were amplified and sequenced. Microsatellite loci were sought with SSRHunter 1.3.0 ( $\mathrm{Li}$ and Wan, 2005). Fifty-nine clones with microsatellite inserts and sufficient flanking sequences were chosen to design primers by the Primer 5 software (Premier Biosoft International). For all loci, the 5 '-end of the forward primer was attached to an M13 tag (5'-TGTAAAACGACGGCCAGT-3') to facilitate incorporation of a 5'-fluorescent label (Schuelke, 2000).

Initially, new primer pairs were tested by amplifying 6 to 10 specimens to evaluate for polymorphic content. The PCR amplification was performed in a $16-\mu \mathrm{L}$ reaction containing 10 $\mathrm{mM}$ Tris- $\mathrm{HCl}, \mathrm{pH} 8.3,50 \mathrm{mM} \mathrm{KCl}, 1.5 \mathrm{mM} \mathrm{MgCl}, 0.2 \mathrm{mM}$ of each dNTP, $0.1 \mu \mathrm{M}$ forward primer, $0.4 \mu \mathrm{M}$ reverse primer, $0.3 \mu \mathrm{M}$ dye-labeled M13 primer (FAM/HEX/TAMRAD), 0.64 U Taq polymerase (TaKaRa), and $30 \mathrm{ng}$ genomic DNA. The PCR profile consisted of an 
initial denaturation step at $94^{\circ} \mathrm{C}$ for $5 \mathrm{~min}$, followed by 30 cycles of denaturation at $94^{\circ} \mathrm{C}$ for $45 \mathrm{~s}$, primer-specific annealing temperature for $45 \mathrm{~s}$, and extension at $72^{\circ} \mathrm{C}$ for $45 \mathrm{~s}$, and then another 8 cycles of denaturation at $94^{\circ} \mathrm{C}$ for $45 \mathrm{~s}$, annealing at $53^{\circ} \mathrm{C}$ for $45 \mathrm{~s}$, and extension at $72^{\circ} \mathrm{C}$ for $45 \mathrm{~s}$, and then terminating with a final extension at $72^{\circ} \mathrm{C}$ for $10 \mathrm{~min}$. Of 59 primer pairs assessed, 12 primer pairs with highly polymorphic performance were selected for further screening with 37 individuals from Xiamen stocks. The PCR products were checked on a $1.5 \%$ agarose gel and then electrophoresed on an ABI 3730xl sequencer (Applied Biosystems, Foster City, CA, USA) using a ROX 500 size standard (Applied Biosystems). The GeneMarker software (SoftGenetics, State College, PA, USA) was used to confirm all the allele calls.

The number of alleles, observed and expected heterozygosities $\left(H_{\mathrm{O}}\right.$ and $H_{\mathrm{E}}$, respectively), deviation from Hardy-Weinberg equilibrium, and linkage disequilibrium were estimated by Genepop (Rousset, 2008). Sequential Bonferroni's corrections were conducted for multiple comparison tests.

\section{RESULTS}

The loci exhibited high levels of polymorphism, with $H_{\mathrm{O}}$ and $H_{\mathrm{E}}$ varying from 0.270 to 0.944 and 0.439 to 0.942 , respectively. The number of alleles per locus ranged from 8 to 24, with a mean of 13.83 per locus. After Bonferroni's correction, 3 loci (CCG24, CCG39, and CCI52) departed significantly from Hardy-Weinberg equilibrium in the screened samples, and linkage disequilibrium between a pair of loci (G30 and G71) was detected. Details of the microsatellite markers, including the name of each locus and its GenBank No., repeat motif, primer sequences, primer melting temperature, base-pair size range of alleles/locus, number of alleles/locus, $H_{\mathrm{O}}$ and $H_{\mathrm{E}}$, and $\mathrm{P}$ value, are shown in Table 1.

\begin{tabular}{|c|c|c|c|c|c|c|c|c|}
\hline $\begin{array}{l}\text { Locus } \\
\text { GenBank No. }\end{array}$ & Repeat motif & Primer sequences $\left(5^{\prime} \rightarrow 3^{\prime}\right)$ & $\begin{array}{l}\mathrm{Ta} \\
\left({ }^{\circ} \mathrm{C}\right)\end{array}$ & $\begin{array}{l}\text { Size range } \\
\quad(\mathrm{bp})\end{array}$ & $N_{\mathrm{A}}$ & $H_{\mathrm{O}}$ & $H_{\mathrm{E}}$ & $P$ value \\
\hline $\begin{array}{l}\text { CCA10 } \\
\text { JX644946 }\end{array}$ & $(\text { TAAA })_{8}$ & $\begin{array}{l}\text { F: *TTCAAAATAATTGGGTTATAC } \\
\text { R: CTCATCATCTTTGTTAATGTC }\end{array}$ & 51 & $105-197$ & 13 & 0.595 & 0.712 & 0.1531 \\
\hline $\begin{array}{l}\text { CCB20 } \\
\text { JX644947 }\end{array}$ & $(\mathrm{ATTT})_{11}(\mathrm{TG})_{7}$ & $\begin{array}{l}\text { F: *CAATGCAGAGTTAGGGGC } \\
\text { R: GATAAGGTCCGCACAGCT }\end{array}$ & 56 & $141-283$ & 17 & 0.686 & 0.798 & 0.0867 \\
\hline $\begin{array}{l}\text { CCG24 } \\
\text { JX644948 }\end{array}$ & $(\text { TATC })_{19}$ TATG $(\text { TATC })_{18}$ & $\begin{array}{l}\text { F: *AATTAAATAATTGCGCCAG } \\
\text { R: CCACAAATACCCTCATCCA }\end{array}$ & 51 & $147-265$ & 9 & 0.270 & 0.439 & $0.0000^{*}$ \\
\hline $\begin{array}{l}\text { CCG30 } \\
\text { JX644949 }\end{array}$ & $(\text { TATT })_{11}$ & $\begin{array}{l}\text { F: *TAAGGGTCCATGTGCTTCAC } \\
\text { R: GAGCTGCTTCCATCAATTTC }\end{array}$ & 56 & $109-181$ & 12 & 0.784 & 0.892 & 0.3248 \\
\hline $\begin{array}{l}\text { CCG39 } \\
\text { JX644950 }\end{array}$ & $(\mathrm{TAAA})_{4} \mathrm{TG}(\mathrm{TAAA})_{6}$ & $\begin{array}{l}\text { F: *GTCGTCAGACTATGGACAGCAC } \\
\text { R: TAATACGCCGTCGTAATTAACA }\end{array}$ & 50 & $117-197$ & 12 & 0.629 & 0.916 & $0.0035^{\#}$ \\
\hline $\begin{array}{l}\text { CCG71 } \\
\text { JX644951 }\end{array}$ & $(\text { GATA })_{22}$ & $\begin{array}{l}\text { F: *CGATACTTTCATTTAGGTT } \\
\text { R: GTCTGCTTTGTAGTGTTCA }\end{array}$ & 55 & $179-283$ & 24 & 0.919 & 0.928 & 0.9059 \\
\hline $\begin{array}{l}\text { CCH22 } \\
\text { JX644952 }\end{array}$ & $(\mathrm{ATTT})_{8}$ & $\begin{array}{l}\text { F: *AAGGGTTTGGGGTTACATT } \\
\text { R: GGTTGATTTGAAACAGGCA }\end{array}$ & 51 & $132-204$ & 8 & 0.500 & 0.672 & 0.0055 \\
\hline $\begin{array}{l}\text { CCI34 } \\
\text { JX644953 }\end{array}$ & $(\text { TTTA })_{9}$ & $\begin{array}{l}\text { F: *GCTGTTGGGCTTCCTCTT } \\
\text { R: TCCTGGCAGTCATTTGTT }\end{array}$ & 55 & $97-137$ & 10 & 0.622 & 0.631 & 0.5450 \\
\hline $\begin{array}{l}\text { CCI52 } \\
\text { JX644954 }\end{array}$ & $(\mathrm{TCTA})_{6} \mathrm{TTTA}(\mathrm{TCTA})_{30}$ & $\begin{array}{l}\text { F: *CTGTCATTTGGTTTTAGC } \\
\text { R: TTTGTGTGTATGCGTGTA }\end{array}$ & 55 & $147-313$ & 17 & 0.306 & 0.912 & $0.0000^{\sharp}$ \\
\hline $\begin{array}{l}\text { CCI55 } \\
\text { JX644955 }\end{array}$ & $(\text { TAAA })_{10}$ & $\begin{array}{l}\text { F: *CAAAAATAGTAACCCTCC } \\
\text { R: CAAATGAGATGTTGGATG }\end{array}$ & 56 & $99-167$ & 13 & 0.757 & 0.839 & 0.7991 \\
\hline $\begin{array}{l}\text { CCJ20 } \\
\text { JX644956 }\end{array}$ & $(\mathrm{CAAT})_{15} \mathrm{CAAC}(\mathrm{CAAT})_{4}$ & $\begin{array}{l}\text { F: *CCAAAACATACAGAACCGTG } \\
\text { R: GAAATGCCTGCTCCATTACA }\end{array}$ & 55 & $98-164$ & 13 & 0.806 & 0.778 & 0.0098 \\
\hline $\begin{array}{l}\text { CCJ29 } \\
\text { JX644957 }\end{array}$ & $\begin{array}{l}(\text { ATCA })_{10} \text { ATCG }(\text { ATCA })_{11} \\
(\text { ATCT })_{13}\end{array}$ & $\begin{array}{l}\text { F: *CAAATAACAAATCAAGAAAG } \\
\text { R: AGAGACAGACAGACACAAAT }\end{array}$ & 55 & $199-295$ & 19 & 0.944 & 0.942 & 0.6095 \\
\hline
\end{tabular}

$\mathrm{Ta}=$ annealing temperature; $N_{\mathrm{A}}=$ number of alleles; $H_{\mathrm{O}}$ and $H_{\mathrm{E}}=$ observed and expected heterozygosities, respectively; $\mathrm{P}$ value = probability of deviation from Hardy-Weinberg equilibrium. *M13 tag (5'-GTAAAACGACGGCCAG-3') label. \#Significant deviations from Hardy-Weinberg equilibrium after sequential Bonferroni’s corrections. 


\section{DISCUSSION}

As far as we know, this set of markers represents the first microsatellites developed for $C$. chinensis and thus contributes available molecular resources to the genetic study of this species. The preliminary results of high variability over these loci indicate that they could be useful in the evaluation of the genetic variation and genetic population structure of Chinese beard eel.

\section{ACKNOWLEDGMENTS}

Research supported by the Nature Science Foundation of China (Grant \#40976094). We are grateful to Dr. Shifeng Wang for the collection of samples.

\section{REFERENCES}

Aggarwal RK, Velavan TP, Udaykumar D, Hendre PS, et al. (2004). Development and characterization of novel microsatellite markers from the olive ridley sea turtle (Lepidochelys olivacea). Mol. Ecol. Notes 4: 77-79.

Hoffman JI and Amos W (2005). Microsatellite genotyping errors: detection approaches, common sources and consequences for paternal exclusion. Mol. Ecol. 14: 599-612.

Li Q and Wan JM (2005). SSRHunter: development of a local searching software for SSR sites. Yi Chuan 27: 808-810.

Liu D, Tang WQ, Zhao YH, Gan YL, et al. (2005). Observation on the morphology of the olfactory organ of the eel Cirrhimuraena chinensis (Anguilliformes, Ophichthidae). Acta Zootax. Sin. 30: 453-460.

Rousset F (2008). Genepop'007: A complete re-implementation of the genepop software for Windows and Linux. Mol. Ecol. Resour. 8: 103-106.

Sambrook J, Fritsch EF and Maniatis T (1989). Molecular Cloning: A Laboratory Manual. 2nd edn. Cold Spring Harbor Laboratory Press, Cold Spring Harbor.

Schuelke M (2000). An economic method for the fluorescent labeling of PCR fragments. Nat. Biotechnol. 18: 233-234.

Zane L, Bargelloni L and Patarnello T (2002). Strategies for microsatellite isolation: a review. Mol. Ecol. 11: 1-16.

Zhang YW, Xiao CY and Xu DS (1982). Studies on the metamorphosis of the snake eel Cirrhimuraena chinensis Kaup. Acta Zool. Sin. 28: 177-182.

Zhu YD (1984). The Fishes of Fujian Province (Part 1). Fujian Science and Technology Press, Fuzhou. 